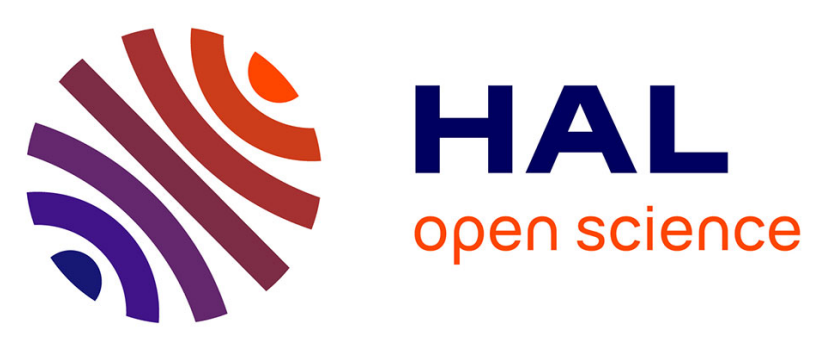

\title{
Sediment concentration in interrill flow: interactions between soil surface conditions, vegetation and rainfall
}

Olivier Cerdan, Yves Le Bissonnais, Véronique Souchère, Philippe Martin, V. Lecomte

\section{- To cite this version:}

Olivier Cerdan, Yves Le Bissonnais, Véronique Souchère, Philippe Martin, V. Lecomte. Sediment concentration in interrill flow: interactions between soil surface conditions, vegetation and rainfall. Earth Surface Processes and Landforms, 2002, 27 (2), pp.193-205. 10.1002/esp.314 . hal-02683165

\section{HAL Id: hal-02683165 \\ https://hal.inrae.fr/hal-02683165}

Submitted on 1 Jun 2020

HAL is a multi-disciplinary open access archive for the deposit and dissemination of scientific research documents, whether they are published or not. The documents may come from teaching and research institutions in France or abroad, or from public or private research centers.
L'archive ouverte pluridisciplinaire HAL, est destinée au dépôt et à la diffusion de documents scientifiques de niveau recherche, publiés ou non, émanant des établissements d'enseignement et de recherche français ou étrangers, des laboratoires publics ou privés. 


\title{
SEDIMENT CONCENTRATION IN INTERRILL FLOW: INTERACTIONS BETWEEN SOIL SURFACE CONDITIONS, VEGETATION AND RAINFALL
}

\author{
O. CERDAN, ${ }^{1} *$ Y. LE BISSONNAIS, ${ }^{1}$ V. SOUCHÈRE, ${ }^{2}$ P. MARTIN ${ }^{2}$ AND V. LECOMTE $^{3}$ \\ 1 Institut National de la Recherche Agronomique, Unité de Science du Sol, Centre de Recherche d'Orléans, BP 20619, 45166 Orléans \\ Cedex, France \\ 2 UMR INRA/INA P-G SAD APT, Centre de recherche de Versailles, 78026 Versailles Cedex, France \\ 3 BRGM - ARN, Avenue Claude Guillemin, BP 6009, 45060 Orléans Cedex, France
}

Received 15 November 2000; Revised 4 July 2001; Accepted 13 September 2001

\begin{abstract}
A database composed of 673 natural rainfall events with sediment concentration measurements at the field or plot scale was analysed. Measurements were conducted on similar soil type (loess soils prone to sealing phenomenon) to apprehend the variability and complexity involved in interrill erosion processes attributable to soil surface conditions. The effects of the dominant controlling factors are not described by means of equations; rather, we established a classification of potential sediment concentration domain according to combination of the dominant parameters. Thereby, significant differences and evolution trends of mean sediment concentration between the different parameter categories are identified. Further, when parameter influences interact, it allows us to discern the relative effects of factors according to their respective degree of expression. It was shown that crop cover had a major influence on mean sediment concentration, particularly when soil surface roughness is low and when maximum 6-min intensity of rainfall events exceeds $10 \mathrm{~mm} \mathrm{~h}^{-1}: \mathrm{mean}^{-}$ sediment concentration decreases from $8.93 \mathrm{~g}^{-1}$ for $0-20$ per cent of coverage to $0.97 \mathrm{~g} \mathrm{l}^{-1}$ for $21-60$ per cent of coverage. The established classification also indicates that the increase of the maximum 6-min intensity of the rainfall factor leads to a linear increase of mean sediment concentration for crop cover over 21 per cent (e.g. from $2.96 \mathrm{~g} \mathrm{l}^{-1}$ to $14.44 \mathrm{~g} \mathrm{l}^{-1}$ for the $1-5 \mathrm{~cm}$ roughness class) and to an exponential increase for low crop cover (e.g. from $3.92 \mathrm{~g} \mathrm{l}^{-1}$ to $58.76 \mathrm{~g} \mathrm{l}^{-1}$ for the $1-5 \mathrm{~cm}$ roughness class). The implication of this work may bring perspective for erosion prediction modelling and give references for the development of interrill erosion equation. Copyright (c) 2002 John Wiley \& Sons, Ltd.
\end{abstract}

KEY WORDS: interrill erosion; sediment concentration; sealing; crop cover; roughness

\section{INTRODUCTION}

Process-based erosion prediction models that apply on agricultural land most often rely on the rill-interrill concept (Foster and Meyer, 1975; Meyer et al., 1975) and develop different formalism for each of these domains. Interrill erosion includes processes of detachment by raindrop impact and transport by shallow sheet flow. General interrill erosion model framework, as the first version of the WEPP model (Nearing et al., 1989), was expressed under the form:

$$
D_{i}=f\left(K_{i}, I, S\right)
$$

where $D_{i}$ is the interrill sediment delivery per unit area per unit time, $K_{i}$ is interrill erodibility parameter related to soil properties, $I$ is the rainfall intensity and $S$ is a slope factor. Kinnell demonstrated the advantage of including a transport component in the interrill model by adding a runoff term (Kinnell and Wood, 1992; Kinnell and Cummings, 1993, Kinnell, 1993):

$$
D_{i}=f\left(K_{i}, I, q, S\right)
$$

\footnotetext{
* Correspondence to: O. Cerdan, Institut National de la Recherche Agronomique, Unité de Science du Sol, Centre de Recherche d’Orléans, BP 20619, 45166 Orléans Cedex, France. E-mail: cerdan@orleans.inra.fr
} 
where $q$ is the excess surface water factor. Zhang et al. (1998), after a factorial rainfall simulation experiment, found that neither runoff nor rainfall alone can adequately simulate interrill sediment delivery. Huang (1995) found that sediment delivery related well to either runoff rate or slope steepness in a quadratic model. Further, for the successful modelling of interrill delivery several authors have emphasized the necessity to separate and understand both detachment and transport and the factors controlling their behaviour (Foster, 1990; Nearing et al., 1994; Huang, 1998). As found by Meyer (1981) using rainfall simulator data, the process of soil detachment by raindrop impact can be expressed by the equation:

$$
D=K I^{2}
$$

Foster (1982) and Foster and Lane (1987) expressed detachment on interrill areas by raindrop impact integrating directly the effect of crop cover:

$$
P_{i}=K_{i} I^{2} C_{i} C_{g} C_{s}
$$

where $P_{i}$ is the detachment rate on interrill areas, $C_{i}$ is the factor for the effect of canopy, $C_{g}$ is the factor for the effect of ground cover and $C_{S}$ is the factor for the effect of soil biomass and soil disturbance.

Although the relationships between soil properties and interrill erosion processes have been addressed (Bradford et al., 1987; Le Bissonnais et al., 1995), the development of an equation predicting the soil factor $K_{i}$ as a function of measurable soil properties has not yet been achieved (Agassi and Bradford, 1999). In addition, erodibility $\left(\approx K_{i}\right)$ is not constant for a given soil type and may be highly variable in the field depending on other factors such as surface conditions. Most interrill soil erosion studies are based on laboratory or field rainfall simulation on specific soil samples, which on the one hand permits control of all the variables in order to study in detail one process, but on the other hand, restricts the range of possible applications of the results as erosion processes are known to be dependent upon methodologies. Further, numerous studies investigated the processes of wash erosion and soil particle splash, using laboratory or field rainfall simulators. Various methodologies may lead to various results which are not necessarily related to the specific effect of the variables under study on erosion and infiltration processes (Agassi and Bradford, 1999).

The objective of this study is to explicitly express potential sediment concentration in interrill flow as a function of surface condition factors on the basis of long-term field experiments. The effects of the dominant controlling factors are accounted for by establishing a classification of uniform potential sediment concentration domain according to a combination of the dominant soil surface parameters.

\section{MATERIAL AND METHOD}

\section{Description of the database}

A total of 673 rainfall-runoff events with sediment concentration measurements originating from different experiments realized in the Normandie region since 1992 (Tables I and II) were gathered in a common data set. The studied area is covered by silt loam soils developed on the loess Quaternary deposit and containing at least 60 per cent silt in the surface horizons. Soils are classified as Neoluvisol in the French Classification and are described as 'excessively drained' by the USDA (1951) soil drainage classification. Such soils are very sensitive to soil sealing because of their low clay content (130 to $170 \mathrm{~g} \mathrm{~kg}^{-1}$ ) and low organic matter content (10 to $20 \mathrm{~g} \mathrm{~kg}^{-1}$ ). When in arable use, large areas are left bare and open to rainfall during most of the cultural season which, combined with the sensitivity to sealing, renders them vulnerable to runoff and water erosion phenomena. The topography is relatively smooth with slope gradients ranging from 1 to 4 per cent on the plateau and 4 to 10 per cent on valley sides. The soil characteristics show very little variability within the studied area. In addition to rainfall, runoff and sediment delivery monitoring, overland flow patterns, surface roughness, soil sealing stages and rate of soil coverage by vegetation were measured 
Table I. Characteristics of the experimental sites which constituted the erosion measurement data set

\begin{tabular}{|c|c|c|c|c|}
\hline Date & Location & Area $\left(m^{2}\right)$ & Crop type; land use & References \\
\hline 1993-1994 & St-Valery-en-Caux & 20 & $\begin{array}{l}\text { Intercrops (no till, } \\
\text { mouldboard ploughing; } \\
\text { superficial tillage, } \\
\text { mustard) }\end{array}$ & $\begin{array}{l}\text { Martin (1997); Martin } \\
\text { et al. (1999) }\end{array}$ \\
\hline 1993-1994 & Blosseville & $20 ; 500$ & $\begin{array}{l}\text { Mustard, } \\
\text { clover-ray-grass, } \\
\text { mouldboard and } \\
\text { superficial tillage, mulch } \\
\text { ploughed and seedbed } \\
\text { preparation }\end{array}$ & Gallien et al. (1995) \\
\hline $1994-1995$ & Blosseville & 20 & $\begin{array}{l}\text { Intercrops (no till, } \\
\text { mouldboard ploughing; } \\
\text { superficial tillage, } \\
\text { mustard) }\end{array}$ & $\begin{array}{l}\text { Martin (1997); Martin } \\
\text { et al. (1999) }\end{array}$ \\
\hline $1996-1997$ & Englesqueville & 100 & Wheat & Lecomte (1999) \\
\hline $1997-1998$ & Englesqueville & 100 & Wheat & Lecomte (1999) \\
\hline
\end{tabular}

Table II. Characteristics of the rainfall events with erosion measurements

\begin{tabular}{|c|c|c|c|c|c|}
\hline & Mean & Median & Standard deviation & Minimum & Maximum \\
\hline Slope $(\%)$ & $2 \cdot 93$ & $2 \cdot 92$ & $0 \cdot 65$ & 1.59 & $4 \cdot 00$ \\
\hline Rainfall (mm) & $14 \cdot 72$ & $12 \cdot 50$ & 9.99 & 1 & $60 \cdot 00$ \\
\hline Mean intensity $\left(\mathrm{mm} \mathrm{h}^{-1}\right)$ & 1.63 & $1 \cdot 11$ & 1.69 & $0 \cdot 05$ & 11.92 \\
\hline $\operatorname{Max} \mathrm{I} / 6 \mathrm{~m} \mathrm{n}\left(\mathrm{mm} \mathrm{h}^{-1}\right)$ & $13 \cdot 63$ & $9 \cdot 00$ & $14 \cdot 74$ & $1 \cdot 20$ & $99 \cdot 60$ \\
\hline $48 \mathrm{~h}$ antecedent rainfall amount $(\mathrm{mm})$ & 8.63 & $3 \cdot 39$ & $13 \cdot 24$ & 0 & 57.44 \\
\hline Runoff ratio (\%) & $6 \cdot 80$ & $2 \cdot 71$ & $9 \cdot 40$ & 0 & $69 \cdot 29$ \\
\hline Sediment concentration $\left(\mathrm{g} \mathrm{l}^{-1}\right)$ & $9 \cdot 20$ & $3 \cdot 00$ & $16 \cdot 39$ & 0 & $104 \cdot 27$ \\
\hline
\end{tabular}

semi-quantitatively twice a month during the period of study (Auzet et al., 1995; Ludwig et al., 1995; Le Bissonnais et al., 1998).

Variables present in the database are: area $\left(\mathrm{m}^{2}\right)$, slope (per cent), land use, roughness (in five classes: 0-1 cm, 1-2 cm, 2-5 cm, 5-10 cm, >10 cm), soil surface degradation stage (four stages: (i) non-sealed: initial fragmentary structure with all fragments clearly distinguishable; (ii) structural seal: altered fragmentary state with local structural seal; (iii) transitional seal: generalized structural seal with local appearance of depositional seal; (iv) sedimentary seal: continuous state with depositional seal), crop cover (exact percentage of coverage leaves, litter and debris; or notation in three classes: C1, 0-20 per cent, C2, 21-60 per cent, C3, 61-100 per cent), runoff volume (1), rainfall amount $(\mathrm{mm})$, rainfall events mean and 6-min maximum intensity $\left(\mathrm{mm} \mathrm{h}^{-1}\right)$, 48-hour antecedent rainfall amount $(\mathrm{mm})$, and sediment concentration (SC) in the flow $\left(\mathrm{g}^{-1}\right)$. Repartition of sediment concentration values is shown in Figure 1.

\section{Representativeness of the data base}

In order to test the representativeness of the erosion measurements data set in terms of soil surface conditions, field observations have been carried out once every two months up to twice a month on two experimental catchments: Blosseville catchment ( 89 ha) between 1993 and 1998 and Bourville catchment (1100 ha) between 1996 and 1998. The two catchments have different characteristics (physical and land use) and together are representative of the region (Lecomte, 1999). Forty dates of observation (11 in autumn, 12 in winter, 13 in spring and 4 in summer) have been selected so as to represent the different land uses and evolution of soil 


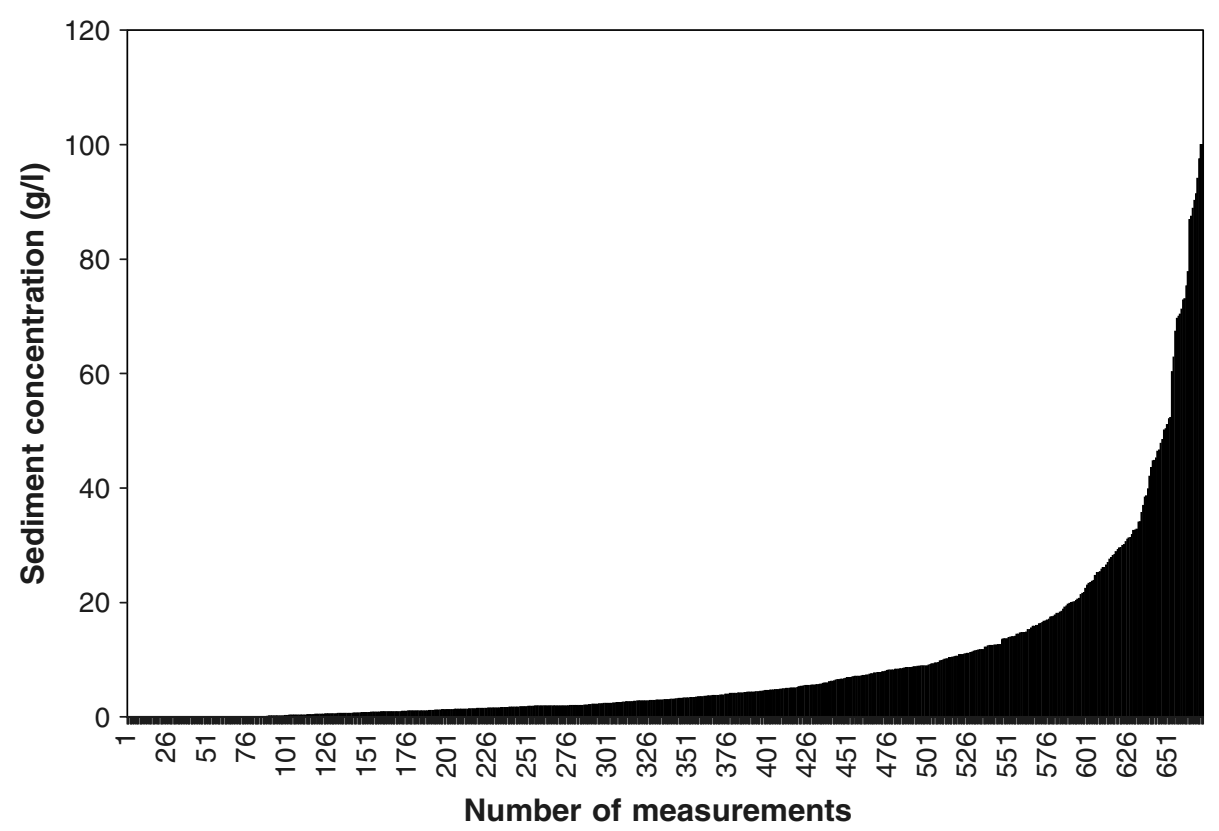

Figure 1. Histogram of the value of sediment concentration for the 673 measurements that constitute the database

surface conditions during a cultural season for the two catchments: 32 for the Blosseville catchment which correspond to 1130 field annotations, and eight for the Bourville catchment which correspond to 4334 field annotations. The field observations have been synthesized in Figure 2. Three combinations stand out from this large survey: bare sealed fields (which account for 38.2 per cent of the winter observations), well developed crops on sealed surfaces (which account for 48.4 per cent of the summer observations) and grassland (14 per cent constant throughout the year) or well developed crops on non-degraded surfaces. A majority of observations are mainly situated in the sedimentary seal class (from 42.1 per cent of the spring observations up to 72 per cent of the winter observations). The experimental measurements of SC which constituted the database (Figure 3) are also mainly situated on soils with degraded surface condition (sedimentary seal class). From the 36 combinations (we only consider combinations which account for at least 0.2 per cent of the total field observation area) that constitute the field observations (Figure 2), 22 are present in the measurement data set which represents 83.8 per cent of the total field observation area. Combinations that are not represented in the SC measurement data set therefore stand for the remaining $16 \cdot 2$ per cent of the total field observation area from which 9.9 per cent are situations with non-degraded soil surface (non-sealed class) associated with well marked roughness $(>5 \mathrm{~cm}$ ). The lack of $\mathrm{SC}$ measurements under such conditions can be explained by the facts that these situations do not often produce runoff, and also because not being key situations, few experiments have been specifically carried out. This database is made of natural rainfall events in field conditions with a long enough time span and with a sufficient number of different measurements to be able to isolate adequately the effects of the various controlling factors.

\section{RESULTS AND DISCUSSION}

\section{Sediment delivery response according to the measured soil surface condition parameters}

For each combination of the parameters describing the soil surface conditions, the number of measurements, the mean value of SC (Figure 4) together with the standard deviation have been calculated. Results show that the classification that has been defined for the data collection and which has already been used in a runoff prediction model for the calculation of potential field infiltration rates (Cerdan et al., 2001) is not the most relevant in terms of sediment particle concentration classification. SC values do not reveal any 


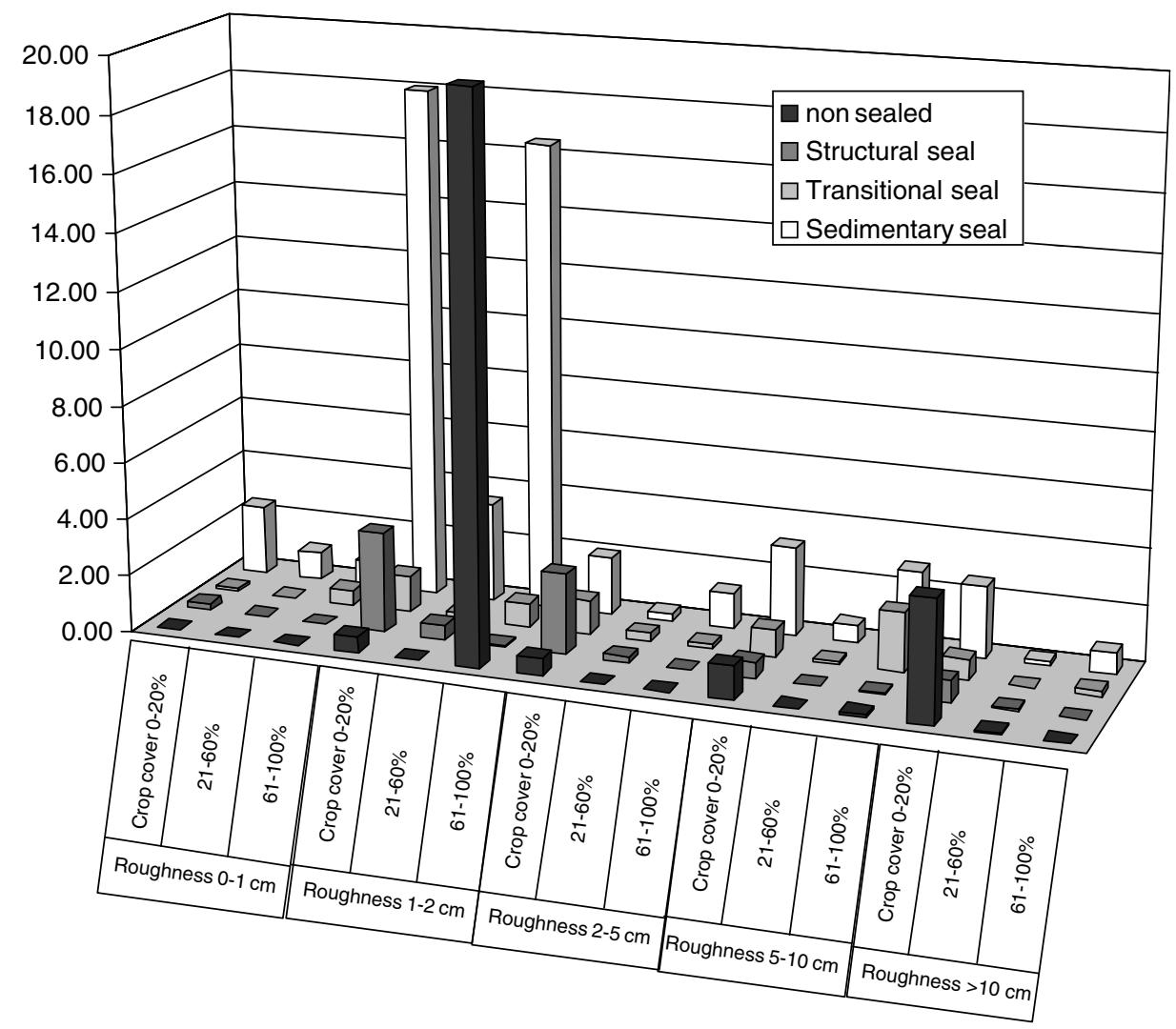

Figure 2. Percentage of observations per class for a total of 5464 field annotations (40 dates of observation at regular time intervals during several cultural seasons for two catchments of 87 and 1100 ha). Non-sealed: initial fragmentary structure, all particles are clearly distinguishable; structural seal: altered fragmentary state with structural seal; transitional seal: local appearance of depositional seal; sedimentary seal: Continuous state with depositional seal

clear trend when passing from one class to the next and the standard deviation values are not satisfactory as most of the time they are of the same order or even higher than the average value, particularly for combinations where roughness is high or where the percentage of crop cover is low. Figure 5 shows that a simpler classification based on only two vegetation cover classes (0-20 per cent 21-60 per cent) and on four roughness classes $(0-1 \mathrm{~cm}, 1-5 \mathrm{~cm}, 5-10 \mathrm{~cm}$ and $>10 \mathrm{~cm})$, gives a better classification of the SC values. Table III describes the effect of roughness. It contains average sediment concentration measured with increasing orientated roughness values for different crop cover and sealing stages. An increase in roughness values leads to an increase of sediment concentrations for all the situations. The increasing trends are similar, independent of crop cover class; only the magnitude of the response varies.

An effect which is hidden in Table III but which is visible on Figure 4, where three crop cover classes are distinguished, is that the increase in sediment concentrations with roughness height is less remarkable when percentage of crop cover exceeds 60 per cent. Another effect of roughness which is not shown in Table III is that even if an increase in roughness was seen to increase average soil suspended particle concentration in the flow, it was seen to decrease total soil loss because it also significantly decreased runoff volume. This remark, already observed by other authors (Johnson et al., 1979; Zobeck and Onstad, 1987) is particularly true for minor rainfall-runoff events, but can be reversed for extreme events. In our observations there are no noticeable interactions between sealing stages and roughness classes.

The effect of crop cover is displayed in Table IV. As mentioned in the Introduction, crop cover is expressed by the percentage of the area, determined by the vertical projection of the cover, i.e. basal and aerial parts 


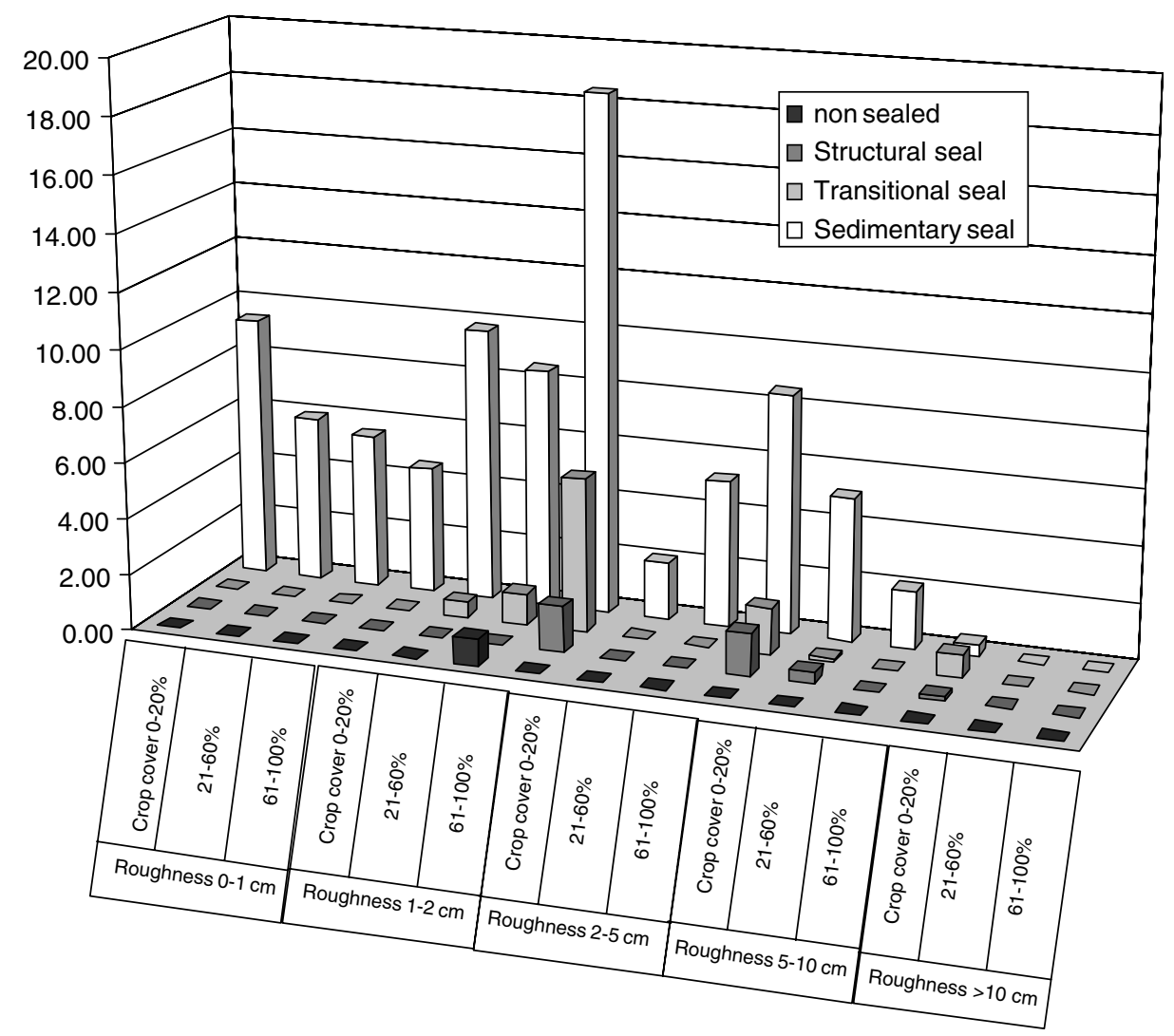

Figure 3. Percentage of sediment concentration measurements per situation contained in the database $(n=673)$. Non-sealed: initial fragmentary structure, all particles are clearly distinguishable; structural seal: altered fragmentary state with structural seal; transitional seal: local appearance of depositional seal; sedimentary seal: continuous state with depositional seal

of plants as well as residues, on the ground surface. Continuous evolution could only be compared on sealed soils, as the degradation of the soil surface structure most often occurred before plants had time to develop. An increase in crop cover leads to a decrease in sediment delivery rates, with values three times lower whatever the roughness class when passing from $0-20$ per cent to 21-100 per cent of coverage. The data set also confirms earlier observations that cover is very effective against rain erosion, and that small amounts have a more than proportional effect (Wischmeier and Smith, 1978; Freebairn and Wockner, 1986): measurements where we have the exact percentage of coverage indicate a dramatic influence up to 20 per cent, and after 40 per cent augmentation in crop cover is less effective. However, even if it is possible to draw general tendencies from this classification, the standard deviation values (Table V) are acceptable only for combinations where percentage of crop cover and roughness are low on partly sealed soils (structural seal) and where percentage of crop cover is high and roughness is low on sealed soils (sedimentary seal). For all the other combinations standard deviation values indicate that the parameters taken into account do not fully described sediment concentration response.

\section{Erodibility and erosivity}

A principal component analysis (PCA) was applied to the matrix composed by eight variables measured on the 673 samples that constituted the database. Since the measurements were on several kinds of measurement scale the analysis was performed on standardized data. The results of the PCA are shown in Table VI and Figure 6. The first component is dominated by orientated and random roughness, sealing stages and percentage of crop cover in descending order of importance and therefore can be defined as the field erodibility axis. 


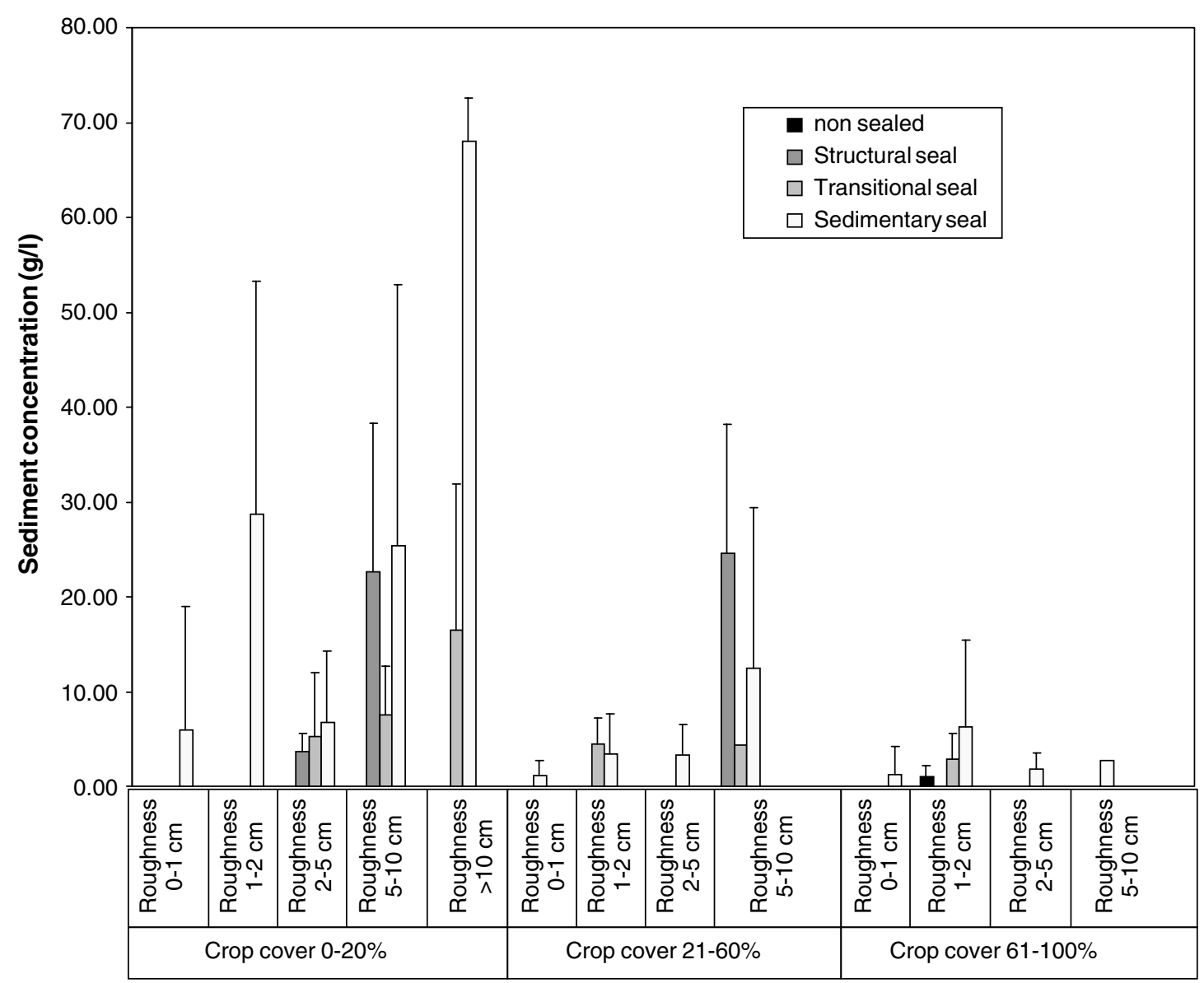

Figure 4. Mean value of sediment concentration $(n=673)$. Non-sealed: initial fragmentary structure, all particles are clearly distinguishable; structural seal: altered fragmentary state with structural crusts; transitional seal: local appearance of depositional seal; sedimentary seal: continuous state with depositional seal. Error bars represent the standard deviations

The second component is explained by rainfall event mean intensity and 6-min maximum intensity and, to a lesser extent, by the percentage of crop cover. This component can consequently be defined as the rain erosivity axis which stands for the potential of the rain to erode. The main indication of PCA is that for our data set, the description of sediment concentration in the flow could be enhanced by the introduction of a rainfall erosivity factor through rainfall mean intensity or rainfall maximum 6-min intensity. The importance of rainfall characteristics in interrill erosion has long been recognized in literature and various indices have been used to account for these processes. However, there is still no general agreement on which rainfall properties actually best describe the mass of sediment detached (Salles and Poesen, 2000). The rainfall erosivity parameter most commonly used is certainly the rainfall intensity. In the WEPP erosion model the square of the average rainfall intensity integrated over the duration of rainfall excess is used to express the combined effect of splash detachment and sheet flow (Nearing et al., 1989). Similarly, various authors have reported an erosivity factor under the form of $I^{p}$ (Meyer, 1981; Kinnell, 1982; Rose et al., 1983; Govers, 1991). In the EUROSEM model (Morgan et al., 1998), the calculation of the amount of soil detached by the rainfall impact is related to the kinetic energy. Wischmeier and Smith (1958) developed a relation between soil loss and the total storm energy multiplied by the maximum 30-min intensity (EI30). Rose (1960) and William (1969) have found best correlation using the rainfall momentum. In most of the studies, rate of soil detachment is related to functions of rainfall intensity, kinetic energy, rainfall momentum or combinations of 


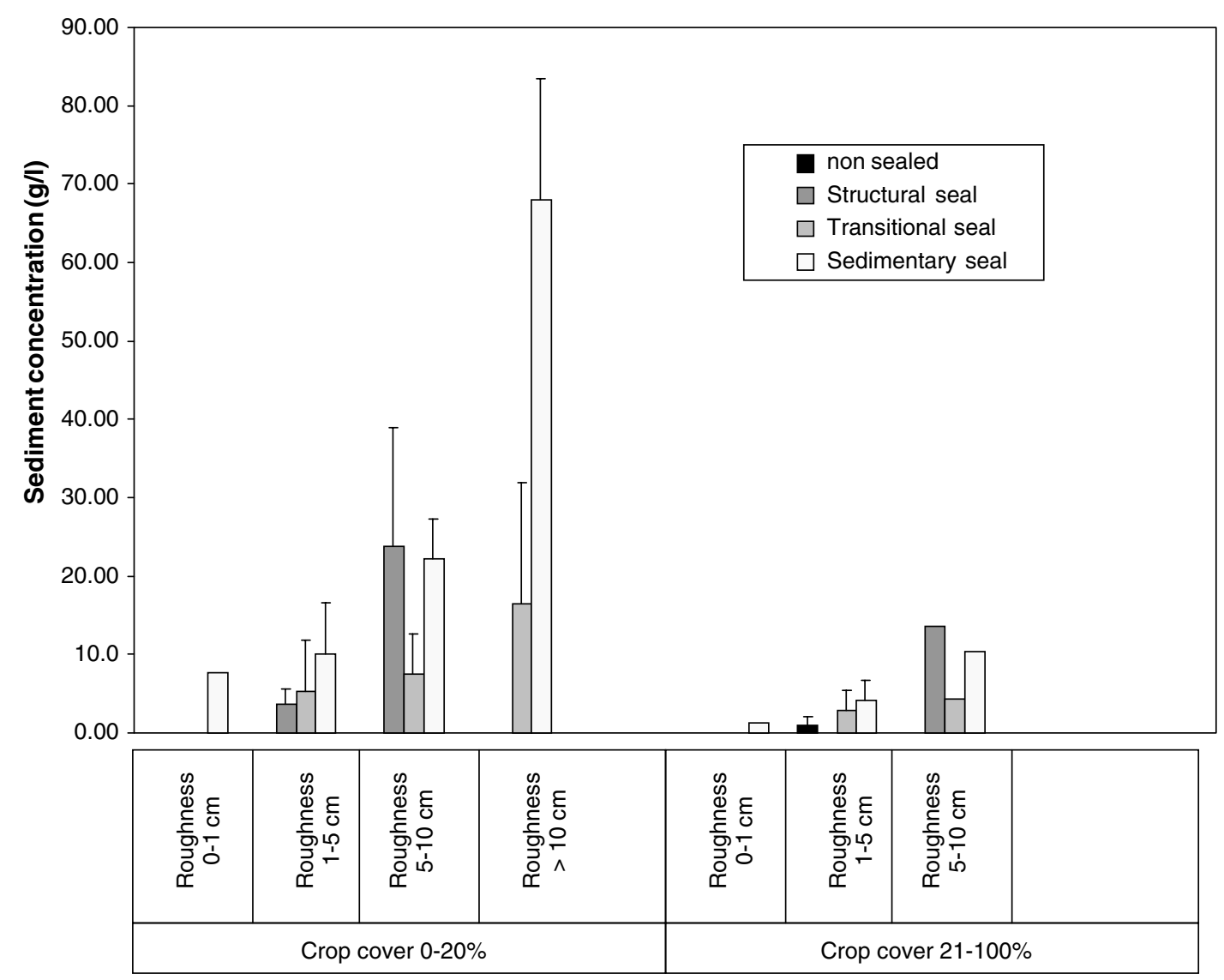

Figure 5. Mean value of sediment concentration $(n=673)$. Non-sealed: initial fragmentary structure, all particles are clearly distinguishable; structural seal: altered fragmentary state with structural seal; transitional seal: local appearance of depositional seal; sedimentary seal: continuous state with depositional seal. Error bars represent the standard deviations

Table III. Effect of roughness on sediment concentration (SC)

\begin{tabular}{|c|c|c|c|c|c|}
\hline Sealing stage & Crop cover $(\%)$ & Roughness $(\mathrm{cm})$ & $\begin{array}{c}\text { Number of } \\
\text { observations }\end{array}$ & $\begin{array}{c}\text { Average SC } \\
\left(\mathrm{g} \mathrm{l}^{-1}\right)\end{array}$ & Standard deviation \\
\hline All sealed stages mixed & $0-20$ & $\begin{array}{c}>10 \\
5-10 \\
1-5\end{array}$ & $\begin{array}{r}9 \\
82 \\
206\end{array}$ & $\begin{array}{c}30 \cdot 28 \\
22 \cdot 5 \\
9 \cdot 59\end{array}$ & $\begin{array}{r}9 \cdot 02 \\
24.92 \\
14.07\end{array}$ \\
\hline \multirow[t]{2}{*}{ Sedimentary seal } & $21-100$ & $\begin{array}{c}5-10 \\
1-5 \\
0-1\end{array}$ & $\begin{array}{r}52 \\
185 \\
83\end{array}$ & $\begin{array}{l}9.69 \\
4.04 \\
1 \cdot 15\end{array}$ & $\begin{array}{r}14 \cdot 92 \\
6 \cdot 22 \\
2 \cdot 44\end{array}$ \\
\hline & $0-20$ & $\begin{array}{c}5-10 \\
1-5 \\
0-1\end{array}$ & $\begin{array}{r}62 \\
166 \\
26\end{array}$ & $\begin{array}{r}25.37 \\
11.04 \\
5.99\end{array}$ & $\begin{array}{l}27.53 \\
15.49 \\
12.95\end{array}$ \\
\hline
\end{tabular}

these according to the specificity of the experimental designs, i.e. experiments on silty or clayey soils or on sand, previously dry or wet, with very high or low intensity simulated rainfall obtained with different kinds of simulator devices.

For all the combinations where standard deviations are high, we try both the mean intensity and the maximum 6-min intensity parameters to enhance the classification. The mean intensity did not bring any 
Table IV. Effect of crop cover on sediment concentration (SC)

\begin{tabular}{lccccr}
\hline Sealing stage & Roughness $(\mathrm{cm})$ & Crop cover $(\%)$ & $\begin{array}{c}\text { Number of } \\
\text { observations }\end{array}$ & $\begin{array}{c}\text { Average SC } \\
\left(\mathrm{g} \mathrm{l}^{-1}\right)\end{array}$ & Standard deviation \\
\hline Sedimentary seal & $5-10$ & $21-100$ & 52 & $9 \cdot 69$ & 14.92 \\
& & $0-20$ & 62 & $25 \cdot 37$ & $27 \cdot 53$ \\
& $1-5$ & $21-100$ & 185 & 4.04 & $6 \cdot 22$ \\
& $0-20$ & $21-100$ & 83 & $11 \cdot 04$ & $15 \cdot 49$ \\
& $0-1$ & $0-20$ & 26 & $5 \cdot 99$ & 12.94 \\
\hline
\end{tabular}

Table V. Average sediment concentration (SC) for combinations of soil surface factors with more than 10 measurements

\begin{tabular}{lcccrr}
\hline $\begin{array}{c}\text { Crop cover } \\
(\%)\end{array}$ & $\begin{array}{c}\text { Sealing } \\
\text { stage }\end{array}$ & $\begin{array}{c}\text { Roughness } \\
(\mathrm{cm})\end{array}$ & $\begin{array}{c}\text { Number of } \\
\text { observations }\end{array}$ & $\begin{array}{c}\text { Average } \\
\text { SC(g/l) }\end{array}$ & $\begin{array}{r}\text { Standard } \\
\text { deviation }\end{array}$ \\
\hline $21-100$ & Sedimentary seal & $5-10$ & 52 & $9 \cdot 69$ & $14 \cdot 92$ \\
& & $1-5$ & 185 & $4 \cdot 04$ & $6 \cdot 22$ \\
& & $0-1$ & 83 & $1 \cdot 15$ & $2 \cdot 44$ \\
$0-20$ & Sedimentary seal & $5-10$ & 62 & $25 \cdot 37$ & $27 \cdot 53$ \\
& & $1-5$ & 166 & $11 \cdot 04$ & $15 \cdot 49$ \\
& & $0-1$ & 26 & $5 \cdot 99$ & $12 \cdot 95$ \\
& & $1-5$ & 11 & $5 \cdot 29$ & $6 \cdot 70$ \\
& Transitional seal & $5-10$ & 12 & $22 \cdot 59$ & $15 \cdot 69$ \\
& Structural seal & $1-5$ & & $3 \cdot 65$ & 1.98 \\
\hline
\end{tabular}

Table VI. Relative contributions of the variables to the two first components (/10000) in the principal component analysis

\begin{tabular}{lcc}
\hline Variable & Component 1 & Component 2 \\
\hline Orientated roughness & 6751 & 475 \\
Random roughness & 5620 & 2536 \\
Sealing & 3498 & 210 \\
Crop cover & 2486 & 1753 \\
Mean intensity & 1930 & 5457 \\
6-min maximum intensity & 2852 & 4202 \\
Runoff ratio & 79 & 100 \\
\hline
\end{tabular}

improvement. One reason could be attributed to problems with the definition of a rainfall event: to calculate the mean intensity when using a rainfall simulator is rather straightforward, when dealing with a natural rainfall events it implies definition of the temporal limits of the events. In our context of intermittent rainfall regime it is difficult to distinguish between contiguous rainfall events with thresholds just based on rainfall characteristics, that is to say which do not rely on the measurement methods (size of the plots) or upon the nature of the studied variables (e.g. if time with no rainfall exceeds the time for the upslope rainfall to flow to the outlet if runoff or sediment yield is the variable of interest).

Table VII shows the variance explained by the maximum 6-min intensity parameter, according to the coefficient of determination, for the combinations where the mean sediment concentrations were not representative. For combinations where crop cover is superior to 21 per cent and where roughness exceeds $5 \mathrm{~cm}$ (except 


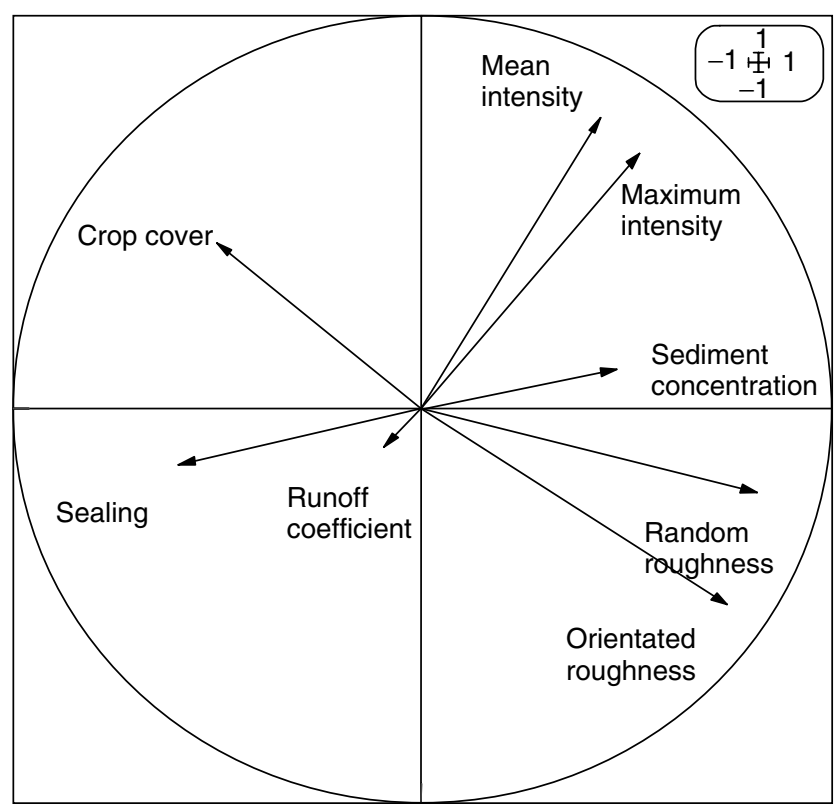

Figure 6. Principal component analysis (first and second components)

Table VII. Situations where the maximum 6-min intensity factor (max 6-min I) explain the variance of sediment concentration $(\mathrm{SC})$

\begin{tabular}{lclcrrr}
\hline $\begin{array}{c}\text { Crop cover } \\
(\%)\end{array}$ & $\begin{array}{c}\text { Orientated roughness } \\
(\mathrm{cm})\end{array}$ & \multicolumn{1}{c}{$\begin{array}{c}\text { Sealing } \\
\text { stage }\end{array}$} & $\begin{array}{c}\text { Number of } \\
\text { observations }\end{array}$ & $\begin{array}{c}\text { Average SC } \\
(\mathrm{g} / \mathrm{l})^{-1}\end{array}$ & $\begin{array}{c}\text { Standard } \\
\text { deviation }\end{array}$ & $\begin{array}{r}R^{2} \text { max } \\
6-\min \text { I }\end{array}$ \\
\hline $21-60$ & $1-5$ & Sedimentary seal & 88 & $3 \cdot 39$ & $4 \cdot 10$ & 0,320 \\
$0-20$ & $5-10$ & Sedimentary seal & 62 & $25 \cdot 37$ & $27 \cdot 53$ & 0,369 \\
& & Structural seal & 11 & $22 \cdot 59$ & $15 \cdot 69$ & 0,702 \\
& \multirow{2}{*}{$1-5$} & Sedimentary seal & 166 & $11 \cdot 04$ & $15 \cdot 49$ & 0,811 \\
& & Intermediate seal & 39 & $5 \cdot 29$ & $6 \cdot 70$ & 0,752 \\
& \multirow{2}{*}{$0-1$} & Sedimentary seal & 26 & $5 \cdot 99$ & $12 \cdot 95$ & 0,908 \\
\hline
\end{tabular}

in the case of structural seal) the correlation is significant even though only 30 per cent of the variance is explained. For the other combinations we obtain good correlation, with $R^{2}$ ranging from 0.70 up to 0.91 . We therefore used this parameter to further classify the sediment concentrations response. We have defined three classes of maximum 6-min intensity: $0-10 \mathrm{~mm} \mathrm{~h}^{-1}, 10-40 \mathrm{~mm} \mathrm{~h}^{-1}$ and $\geq 40 \mathrm{~mm} \mathrm{~h}^{-1}$. The classification obtained is shown on Figure 7. Sediment concentration evolution trends are clearly noticeable according to the degree of expression of the different chosen parameters. The most remarkable effect which dominates is certainly the effect of crop cover. Whatever the surface structural state, roughness class or maximum 6-min intensity class, there is a decrease of mean sediment concentration when crop cover goes from 0-20 per cent to 21-100 per cent. This effect is attenuated when roughness height exceeds $5 \mathrm{~cm}$, when moving towards non-degraded surface condition or when maximum 6-min intensity is inferior to $10 \mathrm{~mm} \mathrm{~h}^{-1}$, that is to say when rain erosivity controlling influence on particle detachment is less effective and is challenged by wash processes. Roughness influence is well marked when it is superior to $1 \mathrm{~cm}$ and when it is not in the sedimentary seal class, whatever the maximum 6-min intensity class or crop cover class. Roughness influence which diminishes when crop cover exceeds 60 per cent is not visible here because of the crop cover threshold retained in the final classification. The maximum 6-min intensity effect is general: it is exponential when crop 


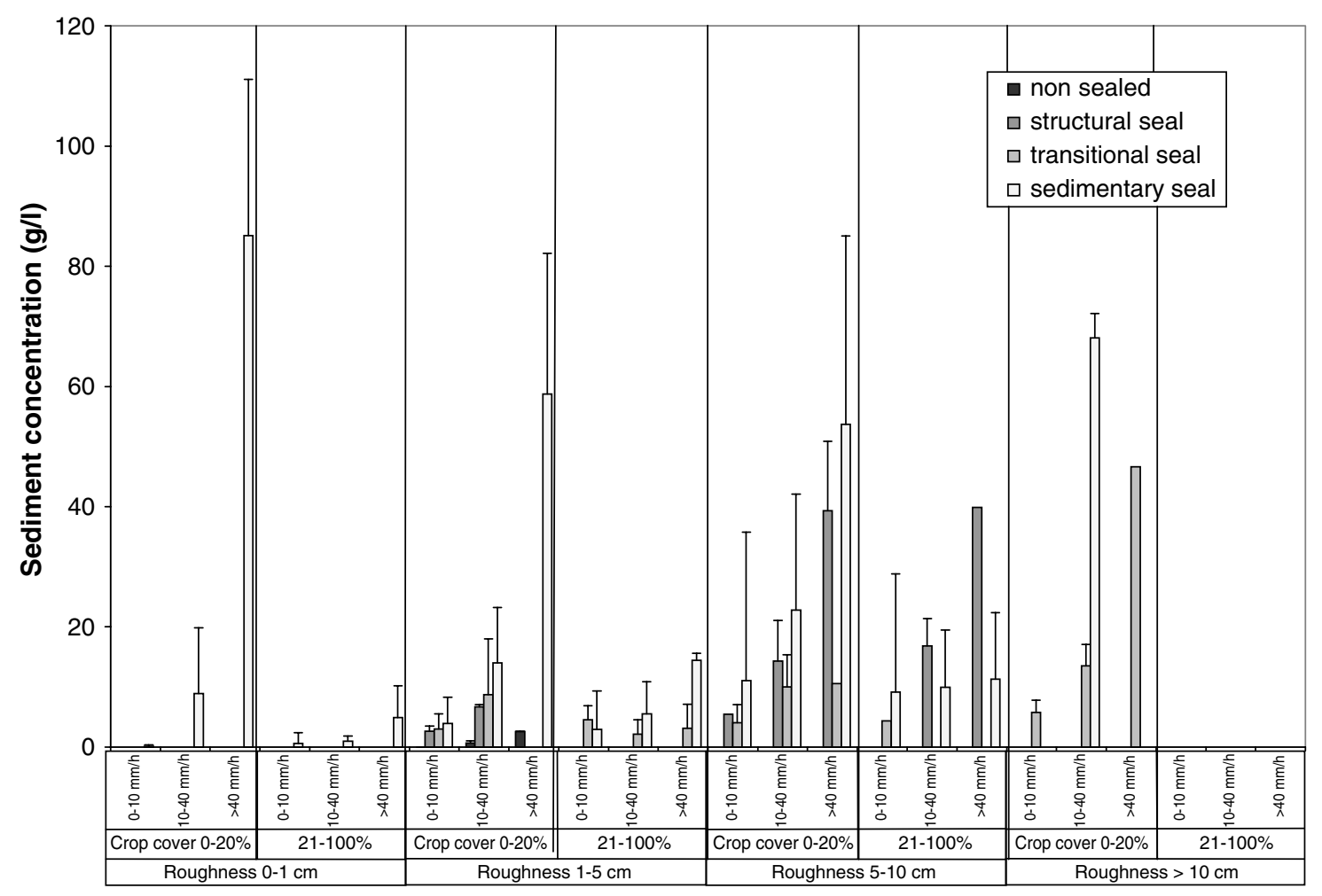

Figure 7. Mean sediment concentration classification. Error bars represent the standard deviations

cover is low and tends to be linear when crop cover is superior to 21 per cent (except the combination of roughness class $5-10 \mathrm{~cm}$ with sedimentary seals). It is not feasible here to determine the influence of surface structural stage according to the other parameters as most of the observations are in the same class.

\section{CONCLUSION}

A database composed of 673 natural rainfall events with sediment concentration measurements along with notation of percentage of crop cover, roughness height, surface sealing stage and rainfall characteristics was analysed. The results of this study show the complexity of processes involved in interrill erosion even though all the observations were conducted on similar soil types. However, significant differences and evolution trends of mean sediment concentration between the different defined parameter categories were identified. Further, when parameter influences interact, it permits factors having a dominant effect to be discerned according to their respective degree of expression. Thereby it was shown that crop cover had a major influence on mean sediment concentration unless roughness exceeded $5 \mathrm{~cm}$ or in the case of rainfall with low maximum 6-min intensity. The established classification also indicates that the increase of the maximum 6-min intensity factor leads to a linear increase of mean sediment concentration for crop cover superior to 21 per cent and to an exponential increase for low crop cover.

The implication of this work may bring perspective for erosion prediction modelling and give references for the development of an interrill erosion equation. It also pinpoints further areas of investigation. Although crop cover is expressed in three classes, for most of the experiments we have measured the exact percentage of area covered by plant leaf and/or plant debris. It would be interesting to separate the two as they do not have the same effect on particle detachment processes. All the experiments have been carried out on slopes with similar gradient (4 per cent). It would also be interesting to study the relationship between mean sediment concentration and slope gradient although soil loss is probably detachment-limited for the range of slope 
gradients observed in the study area since the interrill erosion rate decreases with increasing runoff volume. All the measurements contained in the database were conducted on loess soils prone to sealing phenomena, extension of these experiments for other soil types is also desirable.

\section{REFERENCES}

Agassi M, Bradford JM. 1999. Methodologies for interrill soil erosion studies. Soil and Tillage Research 49: $277-287$.

Auzet AV, Boiffin J, Ludwig B. 1995. Concentrated flow erosion in cultivated catchments: influence of soil surface state. Earth Surface Processes and Landforms 20: 759-767.

Bradford JM, Ferris JE, Remley PA. 1987. Interrill soil erosion processes: Relationship of splash detachment to soil properties. Soil Science Society of America Journal 51: 1571-1575.

Cerdan O, Souchère V, Lecomte V, Couturier A, Le Bissonnais Y. 2001. Incorporating soil surface crusting processes in an expert-based runoff and erosion model STREAM (Sealing Transfer Runoff Erosion Agricultural Modification). Catena 46: 189-205.

Foster GR. 1990. Process-based modelling of soil erosion by water on agricultural land. In Soil Erosion on Agricultural Land, Boardman J, Foster DL, Dearing JA (eds). John Wiley \& Sons: Chichester; 429-445.

Foster GR, Meyer LD. 1975. Mathematical simulation of upland erosion by fundamental erosion mechanics. In Present and Prospective Technology for Predicting Sediment Yields and Sources. ARS-S-40 publication, USDA-Science and Education Administration: Washington, DC; 190-204.

Foster GR, Lane LJ. 1987. Beyond the USLE: Advancements in soil erosion prediction. In Future Developments in Soil Science Research, Boersma LL (ed.). Soil Science Society of America: Madison, Wisconsin; 315-326.

Freebairn DM, Wockner GH. 1986. A study of soil erosion on vertisols of the Eastern Darling Downs, Queensland. II The effect of soil, rainfall and flow conditions on suspended sediment losses. Australian Journal of Soil Research 24: 159-172.

Gallien E, Le Bissonnais Y, Eimberck M, Benkhadra H, Ligneau L, Ouvry JF, Martin P. 1995. Influence des couverts végétaux de jachère sur le ruissellement et l'érosion diffuse en sol limoneux cultivé. Cahiers Agricultures 4: 171-183.

Govers G. 1991. Spatial and temporal variations in splash detachment: a field study. Catena Supplement 20: 15-24.

Huang C. 1995. Empirical analysis of slope and runoff for sediment delivery from interrill areas. Soil Science Society of America Journal 59: $982-990$.

Huang C. 1998. Sediment regimes under different slope and surface hydrologic conditions. Soil Science Society of America Journal 62: $423-430$.

Johnson CB, Mannering JV, Moldenhauer WC. 1979. Influence of surface roughness and clod size and stability on soil and water losses. Soil Science Society of America Journal 43: 772-777.

Kinnell PIA. 1982. Laboratory studies on the effect of drop size on splash erosion. Journal of Agricultural Engineering Research 27: 431-439.

Kinnell PIA. 1993. Runoff as a factor influencing experimentally determined interrill erodibilities. Australian Journal of Soil Research 31: $341-342$.

Kinnell PIA, Cummings D. 1993. Soil/slope gradient interactions in erosion by rain-impacted flow. Transactions of the American Society of Agricultural Engineers 36: 381-387.

Kinnell PIA, Wood TJ. 1992. Isolating erosivity and erodibility components in erosion by rain impacted flow. Transactions of the American Society of Agricultural Engineers 35: 201-205.

Le Bissonnais Y, Renaux B, Delouche H. 1995. Interactions between soil properties and moisture content in crust formation, runoff and interrill erosion from tilled loess soils. Catena 25: 33-46.

Le Bissonnais Y, Benkhadra H, Chaplot V, Fox D, King D, Daroussin J. 1998. Crusting, runoff and sheet erosion on silty loamy soils at various scales and upscaling from $\mathrm{m}^{2}$ to small catchments. Soil and Tillage Research 46: 69-80.

Lecomte V. 1999. Transfert de produits phytosanitaires par le ruissellement et l'érosion de la parcelle au bassin versant - Processus, déterminisme et modélisation spatiale. Thèse de doctorat de l'Ecole Nationale du Génie Rural, des Eaux et Forêts, Spécialité Science de l'Eau.

Ludwig B, Boiffin J, Chadoeuf J, Auzet AV. 1995. Hydrological structure and erosion damage caused by concentrated flow in cultivated catchments. Catena 25: 227-252.

Martin P. 1999. Reducing flood risk from sediment-laden agricultural runoff using intercrop management techniques in northern France. Soil and Tillage Research 52: 233-245.

Martin P, Le Bissonnais Y, Benkhadra H, Ligneau L, Ouvry J-F. 1997. Mesures du ruissellement et de l'érosion diffuse engendrés par les pratiques culturales en Pays de Caux (Normandie). Géomorphologie: Relief, Processus, Environment 2: $143-154$.

Meyer LD. 1981. How rain intensity affects interrill erosion. Transactions of the American Society of Agricultural Engineers 214: $1472-1475$

Meyer LD, Foster GR, Romkens MJM. 1975. Source of soil eroded by water from upland slopes. In Present and Prospective Technology for Predicting Sediment Yields and Sources. Yield Workshop, Oxford, MS, 28-30 November 1972. Publication ARS-S-40. Proceedings of Sediment US Government Printing Office: Washington, DC; 177-189.

Morgan RPC, Quinton JN, Smith RE, Govers G, Poesen JWA, Auerswald K, Chisci G, Torri D, Styczen ME. 1998. The European Soil Erosion Model (EUROSEM): a dynamic approach for predicting sediment transport from fields and small catchments. Earth Surface Processes and Landforms 23: 527-544.

Nearing MA, Foster GR, Lane LJ, Finkner SC. 1989. A process based soil erosion model for USDA-Water Erosion Prediction Project technology. Transactions of the American Society of Agricultural Engineers 32: 1587-1593.

Nearing MA, Lane LJ, Lopes VL. 1994. Modelling soil erosion. In Soil Erosion Research Methods, Lal R (ed.). Soil and Water Conservation Press: St Lucie, FL, USA; 127-156.

Rose CW. 1960. Soil detachment caused by rainfall. Soil Science 89: 28-35.

Rose CW, Williams JR, Sander GC, Barry DA. 1983. A mathematical model of soil erosion and deposition processes: I. Theory for a plane land element. Soil Science Society of America Journal 47: 991-995. 
Salles C, Poesen J. 2000. Rain properties controlling soil splash detachment. Hydrological Processes 14: $271-282$.

USDA Soil Survey Staff. 1951. Soil Survey Manual. United States Department of Agriculture Handbook No. 18. USDA: Washington DC.

William MA. 1969. Prediction of rainfall splash erosion in the seasonally wet tropics. Nature 222: $763-765$.

Wischmeier WH, Smith DD. 1958. Predicting Rainfall Erosion Losses - a Guide to Conservation Planning. US Department of Agriculture Handbook No. 537. Science and Education Administration, United States Department of Agriculture.

Wischmeier WH, Smith DD. 1978. Rainfall energy and its relationship to soil loss. Transactions American Geophysical Union 39: $285-291$.

Zhang XC, Nearing MA, Miller WP, Norton LD, West LT. 1998. Modeling interrill sediment delivery. Soil Science Society of America Journal 62: 438-444.

Zobeck TM, Onstad CA. 1987. Tillage and rainfall effects on random roughness: a review. Soil Tillage Research 9: 1-20. 